\title{
The Impact of Teacher's Self-disclosure on Students' Attitude towards Language Learning in a Foreign Language Context
}

\author{
Sahar Tabatabaee Farani \\ Ferdowsi University of Mashhad, Iran \\ Azar Hosseini Fatemi \\ English Department, Ferdowsi University of Mashhad, Iran
}

\begin{abstract}
This study, conducted in two quantitative and qualitative phases, was designed to investigate the possible impact of teacher's self-disclosure on students' attitude towards English language learning. The participants were 48 female EFL learners of intermediate level who were randomly assigned to experimental (23) and control (25) groups. In the quantitative phase, to check the effect of teacher's self-disclosure on students' attitude, the questionnaire of Attitudes towards English Language was administered in both groups as a pre-test at the beginning and a post-test at the end of the term. During the term, the experimental group received teacher's self-disclosure as treatment. The data were analyzed by means of Independent sample-t-test and matched pair t-test. The results showed significant differences between groups. For the qualitative phase, the experimental group received the questionnaire of the Approval of teacher's self-disclosure. Subjects' responses to the questionnaire and the analysis of teacher's observations confirmed the results of the first phase.
\end{abstract}

Index Terms - attitude, self-disclosure, foreign language context

\section{INTRODUCTION}

Investigations into the factors affecting second language learning are not without any problems. However, research into this area has made an important contribution to the field of English language teaching (ELT) by highlighting those factors that might improve or hinder the process of learning a second or a foreign language. Some of those factors are affective factors that deal with language learners' feelings and emotions. Despite the traditional neglect, these factors have become even more important with the advent of humanistic approaches in SLA. As Williams and Burden said, "Humanistic approaches emphasize the importance of the inner world of the learner and place the individual's thoughts, feelings and emotions at the forefront of all human development" (1997, p. 30).

According to Jourard and Jaffee (1970), self-disclosure is, "the act of revealing personal information to others" (cited in Gilbert, 1976). It is an important element that according to Gilbert (1976) has received considerable attention in the past decade. Self-disclosure can be studied in different areas such as psychology and teaching more specifically in SLA.

One more factor is attitude or the way we look at a thing which in turn affects the way we choose to deal with that thing. Attitude is considered as a very important affective factor in language learning. There are many studies concerning attitude in learning a second or foreign language. To define attitude, Gardner (1985) said, "Attitude has cognitive, affective and conative components (i.e., it involves beliefs, emotional reactions, and behavioral tendencies related to the object of attitude) and consists, in broad terms, of an underlying psychological predisposition to act or evaluate behavior in a certain way" (cited in McGroarty, 1996, p. 5). What the importance of attitude in language learning is and whether it affects language learning are some of the questions that are raised when we think of attitude towards language learning. This study is going to investigate the effects of teacher's self-disclosure of his/her language learning experiences on students' attitude towards language learning.

According to Feuerstein's mediation theory, a child's learning right from birth is shaped by the intervention of significant adults. He called these important factors as, "mediators" or "mediating adults" and their experiences as "mediated learning experiences"(Williams \& Burden, 1997, p. 67). He believed that children's cognitive development will be affected by these mediators (Williams \& Burden, 1997, p.67). Along with Feuerstein's idea of "mediation" there is Vygotsky's idea of "zone of proximal development", which also deals with the idea of "mediation" in the process of learning. As Williams and Burden asserted, "the secret of effective learning lies in the nature of social interaction between two or more people with different levels of skill and knowledge. The role of the one with most knowledge, usually a partner or teacher, but often a peer, is to find ways of helping the other to learn" (1997, p. 40). In the case of this study "mediated learning experience" is teacher's self-disclosure that may help students to get familiar with some of the possible challenges in the process of language learning; the teacher has a great role in presenting these experiences (mediators) in a proper way to be effective and successful in making positive attitudes towards learning a foreign 
language in the mind of learners.

There are different methods such as NLP, emotional intelligence and self-disclosure that seem effective on affective factors related to learning a foreign language. The present study will investigate the effect of teacher's self-disclosure on students' attitude toward language learning. If proved to be true, this construct (self-disclosure) will have great implications for language teachers and learners in the process of learning. Moreover, it can be introduced in training courses as a helpful tool to make an intimate relationship between teachers and students.

\section{LITERATURE REVIEW}

\section{A. Humanism}

Humanism emphasizes the development of the whole person rather than focusing solely upon the development and employment of cognitive skills (Williams \& Burden, 1997, p. 30). One of the key figures of humanistic psychology is Carl Rogers whose works identify some key elements of humanistic approaches to education. For example he believed in "natural potential for learning" or the subject matter's "personal relevance to the learner" and "active participation by the learner, i.e. experiential learning" (Williams \& Burden, 1997, p. 35).

Gertrude Moskowitz (1978, p. 11) described the meaning of "humanistic" in language teaching and stated, "Humanistic education is related to a concern for personal development, self-acceptance, and acceptance by others, in other words, making students more human" (cited in Stevick, 1990, p. 24). Moskowitz has emphasized on two major points in relation to humanistic education as "feeling" and "self-actualizing" which is the fifth way of showing the human quality.

\section{B. Self-disclosure}

According to Vogel and Wester self-disclosure is "a process whereby a person verbally reveals private feelings, thoughts, beliefs, or attributes to another person "(2003, p. 351). Or as Jourard and Jaffee (1970) said, "self-disclosure can be described as act of revealing personal information to others "(cited in Gilbert, 1976, p. 221). Derlega, Metts, Petronio and Mergulis stated, "self-disclosure is loosely defined as what individuals verbally reveal about themselves to others (including thoughts, feeling, and experiences), plays a major role in close relationships" (1993, p. 1). Wei, Russell and Zakalik introduced self-disclosure as a way of making "comfort" and said that, "comfort with selfdisclosure" is one of the indices of "social competence" (2005, p. 602).

The content of self-disclosure is not just decided by the discloser, but the context of relationship and the recipient influence what you disclose. Self-disclosure is not considered as an individual construct, in contrary, it is a mutual and reciprocal one. Jourard believed, "a person who discloses much to another may be expected to receive much disclosure from him; and a person who knows a great deal about another should be relatively well known by him" (1971a, p. 14). It is the case that when one person starts to disclose one's personal information or emotions, the other one does the same thing. It confirms the quality of reciprocity in self-disclosure. According to Jourard, "self-disclosure begets selfdisclosure" (1971a, p. 17).

Self-disclosure is called to be one of the important tools that psychotherapists use to create a deep and successful psychotherapeutic relationship. So, if the foreign language classroom is going to be dealt with by a counselor-client (teacher-student) relationship, then, self-disclosure can be used by the teacher as a successful tool.

Moreover, by self-disclosure, the teacher can share his/her own experiences with students and they can benefit from those experiences; and they can know each other in a more effective way. Jourard believed, "I can experience your experience most directly if you disclose it to me" (1971a, p. 78). Because of the fact that self-disclosure is a reciprocal phenomenon, students will disclose their own experiences and problems, so the teacher can help them easier. In addition, by self-disclosure the teacher can know himself or herself better in relation to those students. In this way, he/she can find the best method of teaching which is compatible with him/her. Jourard believed, "when a person has been able to disclose himself utterly to another person, he learns how to increase his contact with his real self, and he may then be better able to direct his destiny on the basis of this knowledge" (1971b, p. 6)

Self-disclosure has been the theme of lots of studies in the field of English language learning, and different results have been found. For example, Pishghadam and Askarzadeh (2009) investigated the impacts of teacher's self-disclosure on students' speaking ability and anxiety. Self-disclosure proved to be of great importance in success in speaking ability and creating intimacy in language learning context.

Goldstein and Benassi (1994) studied the relation between self-disclosure and students' class participation. The results of this investigation indicated that the positive relation between teacher's self-disclosure and students' class participation was more the result of interpersonal atmosphere made by self-disclosure.

Furthermore, the use of teacher's self-disclosure proved effective on lowering language learners' foreign language classroom anxiety (Hosseini \& Tabatabaee, 2010).

Serag (2011) investigated the role of self-disclosure in EFL writing by computers which showed that teachers can promote learning autonomy by including self-disclosure in the writing course.

\section{Attitude}

Attitude or the way that we look at anything, is very important for the way that we choose to deal with that thing. To 
Gardner (1985), "Attitude has cognitive, affective and conative components (i.e., it involves beliefs, emotional reactions, and behavioral tendencies related to the object of attitude) and consists, in broad terms, of an underlying psychological predisposition to act or evaluate behavior in a certain way" (Cited in McGroarty, 1996, p. 5). Wenden (1998) has introduced attitude as "evaluations, valued beliefs, motivations, what is believed to be acceptable, and approaching or avoiding responses towards something" (Cited in Talebinezhad and Azizi, 2013). Attitude is one of the affective factors, and Brown (2001, p. 61) characterized it by a large proportion of emotional involvement such as feelings, self, relationship in a community of learners and emotional ties between language and culture.

Because of the psychological importance of the theme, attitude has been investigated as an interdisciplinary subject in the field of language learning and psychology. As an instance, Karahan (2007) examined the relationship between attitude towards English language and its use in Turkey. The results showed that positive language attitude helps them have positive orientation towards English language learning.

Krashen (1987) showed the relationship between attitude and language learning success by his Monitor Model, which is constituted in part by attitude, many times has the power to either permit or block language input from reaching the part of a learner's brain that acquires language.

Masgoret, Bernaus and Gardner (2001) declared that attitudes and motivation are "key factors that influence the rate and success of second language learning in the classroom" (Cited in Acheson, n. d., p. 38). Nevertheless, success in language learning can itself be a cause of having positive attitude towards learning a foreign language. Sometimes students gain success in language learning and then look at it positively. McGroarty believed, "positive attitudes about language and language learning may be as much the result of success as the cause" (1996, p. 4).

Because positive or negative attitudes are the result of interaction with others, the role of the teacher is very important in changing negative attitude or in maintaining positive attitude. The teacher should try to find the ways to help students to change their negative attitudes towards language learning and language class. Brown believed, "the negative attitude can be changed, often by exposure to reality" (2000, p. 181). On the other hand, according to Dornyei (1990), "in a context in which there is not much daily contact with native speakers of English, learners are not likely to have a clear affective reaction to the specific L2 language group" (Cited in Yashima, Zenuk-Nishide and Shimizu, 2004, p. 124). This study is going to find out whether teacher's self-disclosure can be a helpful way to direct students' attitudes to a positive point.

\section{Methodology}

\section{A. Participants}

This study was conducted with 48 female learners whose age ranged from 14 to 25 . They were all English language learners of intermediate level. They were able to understand and speak English fairly well. They were homogeneous in terms of English language proficiency. Intact group design was used based on their English learning level. Nevertheless, they were randomly assigned to control and experimental groups. There were 25 learners in the control and 23 learners in the experimental group who received teacher's self-disclosure. Both groups were taught by the same teacher (one of the researchers) to remove all of the possible effects of teacher's personality.

\section{B. Instrumentation}

Three instruments were used in this study:

a. 200C of Nelson English language test battery was utilized in this study to check students' homogeneity. It consists of 50 items in the form of multiple-choice questions. At each level, the passing score is intended to be 30 (60\%) (Fowler and Coe, 1976, p. 9).

b. Questionnaire of Attitudes towards English Language: The questionnaire of attitude used in this study was designed by Zainol Abidin, Pour-Mohammadi and Alzwari (2012). There were totally 45 items concerning language attitudes in terms of behavioral, cognitive and emotional aspects of attitude. It was designed in the form of a 5-piont Likert scale ranging from Level 1: strongly disagree to Level 2: strongly agree. The reported value of reliability by Cronbach alpha was 0.878 which showed that the questionnaire was applicable.

The questionnaire was applied in this study as a pre-test at the beginning of the term to measure students' attitude toward English language learning before receiving teacher's self-disclosure and as a post-test at the end of the term after receiving teacher' self-disclosure to check any possible changes in students' attitude as the result of teacher's selfdisclosure.

c. Questionnaire of Approval of Teacher's Self-disclosure: To check students' perception of teacher's self-disclosure and their feeling towards that, the researchers used the questionnaire that was designed by Goldstein and Benassi (1994). The original questionnaire contains 5 sections, and each component consists of 3 items. To reach the goals of this study just the first three sections of the questionnaire were used. The first section contains 3 items and deals with student perception of teacher's self-disclosure. The alpha reported equals 0.77 (alpha=.77). The second section consists of 3 items and deals with student perception of class participation with reported alpha of 0.88 (alpha=0.88). The last section has three items and measures student perception of freedom to participate in class. The alpha of this section is 0.92 (alpha=.92). This questionnaire was used at the end of the term and after the two post-tests.

d. Teacher's Self-disclosure: The teacher self-disclosed her learning experiences and emotions of the period that she 
was a language learner. Self-disclosure, as the independent variable, was used as treatment in the experimental group only.

e. Teacher's Classroom Observation: Teacher's direct observation of the students' feedback and feelings in the experimental group was one of the ways used in this research. These observations were used as data source to analyze the impacts of teacher's self-disclosure.

\section{Design}

The dependent variable in this study was students' attitude toward English language learning and the independent variable was teachers' self-disclosure about her own English language learning experiences and emotions. Age (ranged from 14-25), sex (all female), and level of language proficiency, as measured by Nelson English language test, were variables which were controlled in this study. Since participants were randomly assigned to the control and the experimental groups, the design of this study was quasi-experimental.

\section{Quantitative Data Collection}

Homogeneity of both groups was confirmed by Nelson English language test (test 200C).

Students' attitude was supposed to be checked at the beginning and at the end of the term. The term had 22 sessions, and data collection continued from April 2012 to June 2012.Hence, the questionnaire of attitude was given to the students of both groups on the fourth session as a pre-test. Students had 30 minutes to complete the questionnaire and the teacher provided required explanations.

From the fifth session on, in experimental group, the teacher started to self-disclose and share some of her experiences and emotions of the period that she herself was a language learner. The self-disclosures were presented for 15 times, each at one session. Some of the things that the teacher exactly stated were the problems and obstacles that she had faced while she was a language learner; the ways that she mastered each skill of English language; the kinds of practices that she followed; the long time that she spent on learning English; the kind of affective and emotional situations that she experienced whenever she had a problem in learning something, or she made a mistake in English classes and so on. Students were so eager to share their own experiences with the class and to find solutions for their problems in English language learning among teacher's self-disclosures.

Teacher's self-disclosures comprised of statements like" I thought that making mistakes in front of classmates was too annoying and something to be avoided, but after a while, I understood that it was a sign of learning and improving. So, I decided not to get embarrassed of my mistakes rather I tried to correct them"; "what do you do to be able to keep the learned words in your mind. Using the lightener box is the thing that I experienced and it really worked", "don't worry if it takes you a long time to learn some grammatical points, sometimes I had the same problem when I was a language learner. To overcome this problem I used to study some grammar books and do their exercises, and whenever I had a problem I asked my teacher; practice makes perfect".

Trying to avoid any effects on the results of the study, the teacher (one of the researchers) had the same emotional, behavioral, and methodological performance during the term in both control and experimental groups. Next, at the end of the term, the questionnaire of attitude was given to the students as the post-test. To check any significant difference between the mean scores at the beginning and at the end of the term, a matched-pair t-test was conducted between the mean scores of the pre-test and post-test of attitude in the experimental and control group.

\section{Qualitative Data Collection}

In the qualitative phase of data collection, the teacher took note of her own observations in the experimental group after each session. The teacher recorded the items that she self-disclosed for students and then the students' feedback and their self-disclosures.

For the next step of the qualitative phase of the study, on the twenty first session, the questionnaire of approval and perception of self-disclosure was given to the experimental group to see whether they felt the traces and impacts of teacher's self-disclosure in their class. In fact, the qualitative phase of this study was conducted in the experimental group, because the investigation and analysis of probable changes in the attitude of the participants in the experimental group was intended. The qualitative phase dealt with the process of the impacts of teacher's self-disclosure, but the quantitative phase dealt with the product of teacher's self-disclosure.

\section{Data Analysis Procedure}

This study was designed to find out whether teacher's self-disclosure have any influence on students' attitude to language learning. So, at first, students' homogeneity in terms of language proficiency was checked by a two-tailed independent samples t-test on their language proficiency test score.

Then, because the two control and experimental groups were independent, a two-tailed independent samples t-test was used as pre-test, and once again, after the treatments, as the post-test of attitude.

After the post-test of attitude in both groups, to check any significant difference between the mean scores at the beginning and at the end of the term, a matched t-test (repeated measure t-test) was conducted between the mean scores of the pre-test and post-test of attitude in the experimental group. A matched t-test was conducted between pre-test and post-test of attitude in the control group.

\section{RESULTS AND DiSCUSSION}




\section{A. Homogeneity of Groups in Proficiency and Attitude}

To examine the pre-existing differences between the students' proficiency level in the two groups, an independent samples t-test was performed. As table I shows, there is no significant difference between the means of control and experimental groups. It means that the students of control and experimental groups are homogenous on the part of their English language proficiency with confidence interval of the difference of $95 \%$. This justifies the homogeneity of both groups.

TABLE I.

T-TEST FOR LANGUAGE PROFICIENCY LEVEL

\begin{tabular}{|l|l|l|l|l|l|l|}
\hline \multicolumn{2}{c}{} & \multicolumn{2}{c|}{$\mathrm{t}$-test for Equality of Means } & \multicolumn{2}{l|}{$\begin{array}{l}\text { Mean } \\
\text { Difference }\end{array}$} & $\begin{array}{l}\text { Std. Error } \\
\text { Difference }\end{array}$ \\
\cline { 3 - 7 } & $\mathrm{t}$ & $\mathrm{t}$ & Sig. (2-tailed) & 1.25 & 1.281 \\
\hline $\begin{array}{l}\text { Proficiency language } \\
\text { score in pretest }\end{array}$ & $\begin{array}{l}\text { Equal variances } \\
\text { assumed }\end{array}$ & 1.012 & 46 & 0.317 & 1.29 & 1.190 \\
\cline { 2 - 7 } & $\begin{array}{l}\text { Equal variances } \\
\text { not assumed }\end{array}$ & 1.089 & 40.89 & 0.28 & 1.29 \\
\hline
\end{tabular}

For the next step, the students of control and experimental groups were tested for their attitude scores at the beginning of the term. Hence, they all answered the questionnaire; mean scores were calculated; and a two-tailed independent samples t-test was performed between them. Table II shows the details.

The comparison between the scores of attitude questionnaire in pretest for both control and experimental groups showed no significant difference between groups $(\mathrm{P}=0.139>\alpha=0.05)$.

TABLE II.

T-TEST FOR PRE-TESTS OF ATTITUDE

\begin{tabular}{|c|c|c|c|c|c|c|}
\hline & \multicolumn{5}{|c|}{ t-test for Equality of Means } \\
\hline & & $\mathrm{t}$ & $d f$ & Sig.(2-tailed) & Mean Difference & $\begin{array}{l}\text { Std. Error } \\
\text { Difference }\end{array}$ \\
\hline \multirow{2}{*}{$\begin{array}{l}\text { Attitude } \\
\text { score in } \\
\text { pretest }\end{array}$} & $\begin{array}{l}\text { Equal variances } \\
\text { assumed }\end{array}$ & -1.51 & 46.000 & 0.139 & -4.042 & 2.685 \\
\hline & $\begin{array}{l}\text { Equal variances } \\
\text { not assumed }\end{array}$ & -1.56 & 45.998 & 0.127 & -4.042 & 2.599 \\
\hline
\end{tabular}

\section{B. Variability Due to Attitude}

To see whether teacher's self-disclosure was effective on students' attitude to language learning, the attitude questionnaire was given to the students of both groups at the end of the term. The mean scores were calculated, and a two-tailed independent samples t-test was performed between the mean scores of post-tests of both groups, see Table III.

TABLE III.

PARTICIPANTS' Performance AND INDEPENDENT SAMPLES T-TEST ON THE ATTITUDE QUESTIONNAIRE FOR EXP. /CON. GROUPS

\begin{tabular}{|c|c|c|c|c|c|c|}
\hline & \multicolumn{5}{|c|}{ t-test for Equality of Means } \\
\hline & & $\mathrm{t}$ & $d f$ & Sig. (2-tailed) & $\begin{array}{l}\text { Mean } \\
\text { Difference }\end{array}$ & $\begin{array}{l}\text { Std. Error } \\
\text { Difference }\end{array}$ \\
\hline \multirow{2}{*}{$\begin{array}{l}\text { Attitude score in } \\
\text { post test }\end{array}$} & $\begin{array}{l}\text { Equal variances } \\
\text { assumed }\end{array}$ & -4.018 & 46.000 & 0.000 & -12.063 & 3.003 \\
\hline & $\begin{array}{l}\text { Equal variances not } \\
\text { assumed }\end{array}$ & -4.221 & 45.034 & 0.000 & -12.063 & 2.858 \\
\hline
\end{tabular}

The results showed that there was a significant difference between the mean scores of two groups in post-test (Pvalue $=0.000<\alpha=0.05$ ).

To make sure that the increase of attitude scores in post-test of the experimental group was a significant one, a paired samples t-test was performed between the mean scores of attitude in pre-test and post-test for the experimental group only.

TABLE IV.

PAIRED SAMPLES T-TEST FOR PRE-TEST \& POST-TEST OF ATTITUDE IN THE EXP. GROUP

\begin{tabular}{|l|l|l|l|l|}
\hline \multicolumn{2}{|l|}{} & $\mathrm{t}$ & $\mathrm{df}$ & Sig. (2-tailed) \\
\hline Pair 1 & $\begin{array}{l}\text { Attitude Score for Experimental Group in Pretest - Attitude } \\
\text { Score for Experimental Group in Posttest }\end{array}$ & 4.709 & 22 & 0.047 \\
\hline
\end{tabular}

Table IV shows that there is a significant difference between the pre-test and post-test of attitude in the experimental group which justifies the positive impact of teacher's self-disclosure (P-value $=0.047<\alpha=0.05$ ). 
The same statistical procedures were performed for the control group. Paired samples t-test was conducted between the mean scores of the pre-test and post-test of attitude in the control group.

TABLE V.

PAIRED SAMPLES T-TEST ON THE PRE-TEST AND POST-TEST OF CON. GROUP PARTICIPANTS’ PERFORMANCE

\begin{tabular}{|l|l|l|l|l|l|l|l|}
\hline \multirow{2}{*}{} & Paired Differences & Std. Deviation & $\begin{array}{l}\text { Std. Error } \\
\text { Mean }\end{array}$ & $\mathrm{t}$ & df & \multicolumn{2}{|c|}{ Sig. (2-tailed) } \\
\cline { 2 - 6 } Pair 1 & $\begin{array}{l}\text { Attitude Scores for } \\
\text { Control Group in } \\
\text { Pretest and Posttest }\end{array}$ & 3.18 & 14.702 & 2.829 & 1.126 & 24 & 0.271 \\
\hline
\end{tabular}

See table V. The results indicate that there was not a significant difference between the mean scores of the pre-test and post-test of attitude in the control group ( $\mathrm{P}$-value $=0.271>\alpha=0.05$ ). Therefore, if we compare the performance of the two groups, we can say that teacher's self-disclosure had positive impact on improving students' attitude towards English language learning in the experimental group while the control group showed no significant difference concerning their attitudes.

\section{Qualitative Analysis}

In order to examine clearly and carefully the effect of teacher's self-disclosure on students' attitude, the researcher (the teacher herself) used the observation technique and recorded the reactions and feedbacks of the students in the experimental group to teacher's self-disclosure. As Mason (1996, p. 60) noted, observations are, "methods of generating data which involve the researcher immersing [him or herself] in a research setting, and systematically observing dimensions of that setting, interactions, relationships, actions, events, and so on, within it" (Cited in Mackey \& Gass, 2005 , p. 175). In the case of this study, the teacher self-disclosed her feelings and experiences, then, she observed students' feedbacks carefully, and after that, she took note of whatever they said as a reaction. When self-disclosures started, students just listened for the first and the second times. But after two or three sessions, they started to react. Actually, they responded to teacher's self-disclosure. The teacher self-disclosed some of the problems that she faced during her language learning and students shared their own.

For example, one session when the teacher wanted to teach vocabulary, she said, "When I was a language learner, I had problems memorizing new words". Then she continued that she used some vocabulary books and a lightener box to solve this problem and it was effective. In response to expressing this experience, most of the students answered that they had the same problem. For instance, one of them said, "memorizing new words is one of my problems. When I want to say something, I cannot remember the words so that I forget what I was going to say. If these vocabulary books or the lightener box help me, I can solve one of my biggest problems in language learning".

The teacher noticed that after each self-disclosure about something, students' behavior toward that point changed. For example, one session, the teacher said that making mistakes is one of the steps and a sign of language learning. She told when she was a language learner, she was so careful about making mistakes so that sometimes she preferred not to say anything in English in the classroom to protect her ego. In other words, because of the fear of making mistakes in front of the classmates, she avoided to speak in English. After this self-disclosure, students got surprised and one of them said, "I thought that making mistakes is an obstacle that I cannot overcome. I thought that language teachers have not had such kinds of problems and I will not be as proficient as you are. But now, I know that I can be as good as you in the future".

The teacher could see that whenever she self-disclosed one of her emotions during her language learning period, or explained some of her experiences, students did the same thing, they were more intimate than before, they could talk about their feelings about English language itself and also learning English, they talked about the way that they looked at English. After that, they got relaxed and they made sure that they could solve their problems. As an instance one of them said, "I did not like English language and I did not want to continue learning it, because I had a lot of problems in learning English. I had decided not to come to English class anymore. But after I understood that such feelings and problems are natural part of language learning and I should find the best ways to deal with them, I got encouraged to continue".

To make sure that teacher's self-disclosure was sufficient to be felt and understood by the experimental group, the teacher gave them the questionnaire of approval of teacher's self-disclosure at the end of the term. The teacher carefully examined students' answers to the questionnaire, which were in the form of self-report. The researcher compared the recorded class observations with the self-reports and concluded that qualitatively teacher's self-disclosure could be effective on improving students' attitude toward English language learning. Because they were more eager to communicate with their classmates and they were more interested to participate in class discussions. Besides, since they developed a positive attitude towards language learning, they were not so pessimistic about English language learning as before.

Since, the focus of the qualitative phase of this study was on the feedback of students of the experimental group to teacher's self-disclosure inside the classroom, the researcher did not do any statistical analysis on the questionnaire of approval of teacher's self-disclosure. It was just used to be compared with classroom observations and to make sure that 
the teacher was successful in communicating her attitudes through self-disclosure.

\section{CONCLUSION}

The results of this study showed that teacher's self-disclosure can improve students' attitude towards English language learning. Nevertheless, these statistical findings were not the only points that were concluded out of this study. As the results of the qualitative phase of the study demonstrated, teacher's self-disclosure can create a relaxing climate in the classroom that in its turn can encourage students to exchange their experiences with their peer learners and their teacher.

When the students started to talk, teacher's self-disclosure led them into the process of consciousness raising so that the areas of weakness, and the points that required more practice, were revealed.

Learners' autonomy can be introduced as one important indirect conclusion of this study. In fact, the exchange of experiences between the teacher and the students helped the students to learn some of the strategies of learning different skills such as reading or listening. Therefore, the students could move toward autonomy little by little.

It was concluded from this study that teacher's self-disclosure can be a way to improve students' attitude towards language learning. Therefore, it is obvious that teachers can use it to change the negative ideas of cynical students who look at language learning as an obstacle that cannot be overcome. How the teacher self-discloses, can really affect students' way of looking at language learning or the ways they adopt to learn the foreign language hence giving them a new perspective.

Moreover, teacher's self-disclosure can be used by language teachers as a way of creating intimacy between the language teachers and learners in the classroom. It is very important to know the possible and appropriate ways of creating intimate relationships with students. Since "self-disclosure begets self-disclosure", it can encourage the students to talk about their own feelings toward language learning.

In addition, by self-disclosure, the teacher is in a better position to decide how to deal with students' problems. Actually, the teacher can adopt the best methods, techniques, or even classroom activities that are compatible with the students' weaknesses they have talked about in response to teacher's self-disclosure.

The language teachers should learn how to use self-disclosure in the classroom because of its great importance; moreover, it can be introduced in teacher training courses as one of the psycholinguistic elements that have great effects on language learners' affective condition.

Since self-disclosure is an item in the field of psychology that is related to language learning/teaching, it is better to be introduced in courses dealing with psycholinguistics and philosophy of education. Teacher's self-disclosure can be introduced in the books of second/foreign language teaching methods. So, the authorities in the field of materials development for second/ foreign language teaching should take this aspect into consideration.

It can also be useful to make both teachers and students aware of some psychological factors affecting language learning such as attitude. If the students use self-disclosure and talks about the negative outcomes of taking negative attitudes to language learning (or even lack of motivation which is related to attitude), the students will be more eager to overcome such kinds of problems.

\section{REFERENCES}

[1] Acheson, K. (2005). Do our kids have an attitude? A closer look at foreign language classrooms in the United States. Retrieved December 30, 2008, from http://www2.gsu.edu/\% 7Ewwwesl/gswpal/Kris.pdf.

[2] Brown, H. D. (2000). Principles of language learning and teaching. White Plains, NY: Pearson Education.

[3] Brown, H. D. (2001). Teaching by principles: An interactive approach to language principles. White Plains. NY: Pearson Education.

[4] Derlega, V.J., Metts, S., Petronio, S., \& Mergulis, S. T. (1993). Self-disclosure. Sage Publications: International Educational and Professional Publisher, Newbury Park, London, p. 1.

[5] Dornyei, Z. (1990). Conceptualizing motivation in foreign language learning. Language Learning, 40, pp. 45-78.

[6] Fowler, W. S. \& Coe, N. (1976). Nelson English language tests. Thomas Nelson and Sons Ltd. UK: London.

[7] Gardner, R. C. (1985). Social psychology and second language learning: the role of attitudes and motivation. London: Edward Arnold.

[8] Gilbert, S. J. (1976). Self-disclosure, intimacy, and communications in families. The Family Coordinator, 25(3), pp. 221-31.

[9] Goldstein, G. S. \& Benassi, V. A. (1994). The relationship between teacher self-disclosure and student classroom participation. Teaching of Psychology, 21(4), pp. 212-17.

[10] Hosseini, A. F. \& Tabatabaee, S. F. (2010). Therapeutic application of teacher's self-disclosure on the reduction of students' foreign language classroom anxiety. Ferdowsi review: An Iranian journal of TESL, literature and translation studies, 1(3), pp. $25-52$.

[11] Jourard, S. M. (1971a). Self-disclosure: an experimental analysis of the transparent self. New York: John Wiley \& Sons Inc.

[12] Jourard, S. M. (1971b). The transparent self. New York: Litton Educational Publishing Inc.

[13] Jourard, S. M. \& Jaffee, P. E. (1970). Influence of an interviewer's disclosure on the self-disclosing behavior of interviewees. Journal of Counseling Psychology, 17, pp. 252-257.

[14] Karahan, F. (2007). Language attitudes of Turkish students toward the English language and its use in Turkish context. Journal of Arts and Sciences, 7, pp.73-87.

[15] Krashen, S. D. (1987). Principles and practice in second language acquisition. Prentice-Hall International. UK: London. 
[16] Mackey, A. \& Gass, S. M. (2005). Second language research: Methodology and design. New Jersey: Lawrence Erlbaum Associates, Inc., Publishers.

[17] Masgoret, A. M., Bernaus, M. \& Gardner, R. C. (2001). Examining the role of attitudes and motivation outside of the formal classroom: a test of the mini-AMTB for children. In Z. Dornyei and R. Schmidt (Eds.) Motivation and second language acquisition. (Technical Report, 23, pp. 281-295). Honolulu: University of Hawaii, Second Language Teaching and Curriculum Center.

[18] Mason, J. (1996). Qualitative researching. London: Sage.

[19] McGroarty, M. (1996). Language attitudes, motivation, and standards. In S. L. McKay \& N. H. Hornberger (Eds.), Sociolinguistics and language teaching, (pp. 3-46). The United States of America: Cambridge University Press.

[20] Moskowitz, G. (1978). Caring and sharing in the foreign language class: a sourcebook on humanistic techniques. Rowley, Mass: Newbury House.

[21] Pishghadam, R. \& Askarzadeh Torghabeh, R. (2009). The impacts of teacher self-disclosure on the speaking ability of EFL learners. Iranian EFL journal, Vol. 3, pp. 37- 46.

[22] Serag, A. (2011). Self-disclosure in EFL writing by computers. In A. Steward (Ed.), JALT2010 Conference Proceedings. (pp. 551-564). Tokyo: JALT.

[23] Stevick, E. W. (1990). Humanism in language teaching: a critical perspective. Oxford: Oxford University Press.

[24] Talebinezhad, M. R. \& Azizi, M. (2013). The Iranian high school students' attitude toward CALL and the use of CALL for EFL receptive skills. Theory and Practice in Language Studies, 3(2). pp. 329-337.

[25] Vogel, D. L. \& Wester, S. R. (2003). To seek help or not to seek help: the risks of self-disclosure. Journal of Counseling Psychology, 50(3), pp. 351-361.

[26] Wei, M., Russell, D. W \& Zakalik, R. A. (2005). Adult attachment, social self-efficacy, self-disclosure, loneliness, and subsequent depression for freshman college students: A longitudinal study. Journal of Counseling Psychology, 52(4), pp. 602614.

[27] Wenden, A. (1998). Learner Strategies for Learner Autonomy. Great Britain: Prentice Hall.

[28] Williams, M. \& Burden, R. L. (1997). Psychology for language teachers: a social constructivist approach. Cambridge: Cambridge University Press.

[29] Yashima, T., Zenuk-Nishide, L. \& Shimizu, K. (2004). The influence of attitudes and affect on willingness to communicate and second language communication. Language Learning, 54(1), pp. 119-152

[30] Zainol Abidin, M. J., Pour-Mohammadi, M. \& Alzwari, H. (2012). EFL students' attitudes towards learning English language: The case of Libyan secondary school students. Asian social Science, 8(2), pp. 119-134.

Sahar Tabatabaee Farani received her BA in English translation from Khayyam University in Mashhad, Iran. Then she received her MA in TEFL from Ferdowsi University of Mashhad, Iran. Her areas of interest include psycholinguistics, sociolinguistics and second language teaching and learning.

Azar Hosseini Fatemi, associate professor in TEFL, is the head of Department of English, Ferdowsi University of Mashhad, Mashhad, Iran. Her areas of interest include issues in second language teaching and learning. 